\title{
Analisis Struktur Mikro Globular Dan Kekerasan Paduan Aluminium ADC12 Pada Pengecoran Semi Solid Dengan Metode Stir Casting
}

\author{
Syaharuddin Rasyid ${ }^{1}$, Abram Tangkemanda ${ }^{2}$, Muh. Hasmar Hasbullah ${ }^{3}$, Muh. Al-Fandi ${ }^{4}$ \\ ${ }^{1}$ Jurusan Teknik Mesin, Politeknik Negeri Ujung Pandang, Makassar 90245, Indonesia \\ *syaharuddinrasyid@poliupg.ac.i
}

\begin{abstract}
This study aims to analyze the effect of the stirrer model, stirring rotation (400, 500, 600 rpm), for 20 seconds, and pouring temperature $\left(565,570\right.$, and $\left.575^{\circ} \mathrm{C}\right)$ on the microstructure and mechanical properties of the aluminum alloy ADC12. The methods of research are a) preparing material aluminum alloy ADC12, b) making molds, c) casting, d) making specimens for testing, e) micro structure testing and hardness testing, $f$ ) analyzing data using Microsoft excel applications. Results of the study show that the smallest grain size occurs in casting parameters: stirrer angle $0^{\circ}, 600 \mathrm{rpm}$ rotation, and pouring temperature $565^{\circ} \mathrm{C}$ with a value of $27.715 \mu \mathrm{m}$. The biggest shape factor occurs in casting parameters: stirrer angle $0^{0}$, rotation $600 \mathrm{rpm}$, and pouring temperature $565^{\circ} \mathrm{C}$ with a value 0.76 . The highest hardness occurs in casting parameters: stirrer angle $0^{0}$, rotation $600 \mathrm{rpm}$, and pouring temperature $565^{\circ} \mathrm{C}$ with a value $88.0 \mathrm{HB}$.
\end{abstract}

Keywords: semi solid, stir casting, aluminum alloy ADC12.

\begin{abstract}
Abstrak: Penelitian ini bertujuan menganalisis pengaruh model pengaduk, putaran pengadukan (400, 500, 600 $\mathrm{rpm})$, selama 20 detik, dan suhu tuang $\left(565,570\right.$, dan $\left.575^{\circ} \mathrm{C}\right)$ terhadap struktur mikro dan sifat mekanik paduan aluminium ADC12. Metode penelitian yang digunakan adalah a) mempersiapkan bahan aluminium paduan $\mathrm{ADC} 12, \mathrm{~b})$ membuat cetakan, c) mengecor, d) membuat spesimen untuk pengujian, e) pengujian stuktur mikro dan pengujian kekerasan, f) menganalisis data menggunakan aplikasi microsoft exel. Hasil penelitian menujukan bahwa ukuran butir terkecil terjadi pada parameter penegcoran: sudut pengaduk $0^{0}$, putaran $600 \mathrm{rpm}$, dan suhu tuang $565^{\circ} \mathrm{C}$ dengan nilai $27,715 \mu \mathrm{m}$. Faktor bentuk terbesar terjadi pada parameter pengecoran: sudut pengaduk $0^{0}$, putaran $600 \mathrm{rpm}$, dan dan suhu tuang $565^{\circ} \mathrm{C}$ dengan nilai 0.76 . Kekerasan tertinggi terjadi pada parameter pengecoran: sudut pengaduk $0^{\circ}$, putaran $600 \mathrm{rpm}$, dan dan suhu tuang $565^{\circ} \mathrm{C}$ dengan nilai $88,0 \mathrm{HB}$.
\end{abstract}

Kata kunci: semi solid, stir casting, paduan aluminium ADC12.

\section{PENDAhuluan}

Kebutuhan akan berbagai produk dan model logam diprediksi akan terus meningkat setiap tahunnya, seperti pembuatan komponen-komponen otomotif dan peralatan-peralatan rumah tangga.

Untuk memenuhi berbagai produk dan model logam yang diprediksi akan terus meningkat tersebut maka teknik pengolahan logam juga mengalami perkembangan yang sangat pesat, terutama dengan cara atau metode yang dipakai. Salah satu metode yang digunakan adalah dengan proses semisolid forming. Proses semisolid forming, disebut juga proses semiliquid forming, semisolid casting atau semiliquid casting adalah proses pengerjaan logam yang dilakukan dalam kondisi campuran fasa cair dan padat (semisolid atau semiliquid). Bila dibandingkan dengan proses pengecoran konvensional, proses semisolid forming memiliki kelebihan karena cacat porositas relatif rendah sehingga keuletan dan kekuatannya relatif tinggi.

Penggunaan aluminium sebagai komponen kendaraan bermotor sangat bervariasi meliputi pada blok mesin, bagian badan (rangka) dan lingkar roda. Penggunaan aluminium dan paduannya ini dikarenakan sifatnya yang ringan dan kuat setelah dipadu dengan unsur lain seperti silikon, mangan, dan tembaga[1].Paduan aluminium die casting 12 (ADC12) adalah salah satu jenis paduan Al-Si dengan penambahan unsur $\mathrm{Cu}, \mathrm{Fe}, \mathrm{Mn}, \mathrm{Mg}, \mathrm{Zn}, \mathrm{Ti}, \mathrm{Cr}, \mathrm{Ni}, \mathrm{Pb}$, dan $\mathrm{Sn}$. 
Rasyid [2,3], membandingkan parameter pengadukan (kecepatan dan waktu) pada sifat mekanik dan struktur mikro paduan aluminium ADC12. Sifat mekanik yang optimal (kekerasan dan kekuatan tarik) diperoleh pada 20 detik waktu pengadukan dan $300 \mathrm{rpm}$ sebesar $135.8 \mathrm{HB}$ dan $246 \mathrm{~N} / \mathrm{mm} 2$. Nilai shape factor maksimum pada penelitian ini adalah 0.42 , sementara itu nilai shape factor yang baik untuk struktur globular adalah minimal 0.6.

Berdasarkan hasil penelitian terdahulu pada proses pengecoran semi solid paduan aluminium ADC12 dengan menggunakan pengaduk mekanik [2], maka masih dimungkinkan dilakukan penelitian lebih lanjut dengan beberapa variasi model pengaduk dan parameter pengadukan yang berbeda.

Dengan masalah diatas maka kami mengambil penelitian dengan teknik pengolahan logam salah satunya yaitu proses semisolid forming sehingga metode yang dilakuan dengan cara menganalisis pengaruh model pengaduk $\left(0^{\circ}, 15^{\circ}\right.$ dan $\left.30^{\circ}\right)$, variasi putaran pengadukan $(400,500,600 \mathrm{rpm})$, dengan waktu pengadukan 20 detik, dan variasi suhu tuang $\left(565,570\right.$, dan $\left.575^{\circ} \mathrm{C}\right)$ terhadap struktur mikro dan sifat mekanik paduan alumunium ADC12.

\section{METODE PENELITIAN}

A. Persiapan Alat dan Bahan

Peralat yang digunakan dalam penelitian ini adalah sebagai berikut: Tungku peleburan, Crucible,cetakan logam,pengukur temperatur jenis infrared,thermokopel,alat pelindung panas, affri hardness tester Series $206 \mathrm{MX}$, jangka sorong, gerinda tangan, gergaji tangan, mesin poles, dan mikroskop optik.Sedangkan bahan yang digunakan dalam penelitian ini yaitu: Aluminium ADC12,kertas tissue, resin + hardener, kertas amplas grid 200, 400, 600, 800, 1000, 1500, 2000, 4000, dan 5000, amplas beludru, cairan intan $3 \mu \mathrm{m}$, wadah spesimen struktur mikro.

\section{B. Prosedur Penelitian}

\section{a. Pembuatan pengaduk dan cetakan logam.}

Pembuatan pengaduk dan cetakan dengan logam dimulai dari proses desain sampai dengan pembuatan dan perakitan. Proses desain meliputi pembuatan sketsa atau gambar dengan menggunakan softwere Autodesk.

\section{b. Pengecoran Aluminium}

Pada pengecoran aluminium ada beberapa hal yang dilakukan, yaitu sebagai berikut:

1.Persiapan peralatan yang akan digunakan pada saat pengecoran aluminum. Mulai dari pemasangan gas elpiji untuk tunggu peleburan dan pemanasan cetakan, stir casting untuk melakukan pengadukan, sampai pengecekan dan alat pengukur suhu yang akan digunakan.

2.Persiapan aluminium ADC12 yang kemudian akan dilebur di tungku peleburan sampai mencapai suhu yang ditentukan dan juga pengduk. Parameter suhu yang digunakan yaitu $565^{\circ} \mathrm{C}, 570{ }^{\circ} \mathrm{C}$, dan $575{ }^{\circ} \mathrm{C}$, parameter cepatan pengadukan $400,500,600$ dan sudut pengaduk $0^{\circ}, 15^{\circ}$ dan $30^{\circ}$.

3.Pemanasan cetakan hingga mencapai suhu yang ditentukan yaitu $565^{\circ} \mathrm{C}$ dan selanjutnya melakukan pengadukan $400 \mathrm{rpm}$ dengan sudut $0^{\circ}$ selama 20 detik.

4. Memeriksa secara berkala suhu dari aluminium lebur dan cetakan yang dipanaskan. Pemeriksaan suhu dengan menggunakan pengukur temperatur thermokopel dan jenis infrared.

5. Apabila aluminium lebur dan cetakan telah mencapai suhu sesuai dan telah diaduk dengan parameter yang sudah ditentukan, selanjutnya yaitu proses penuangan cairan aluminium ke dalam cetaka.

6.Proses terakhir adalah mengeluarkan aluminium dari cetakan. Aluminium yang masih berada di dalam cetakan.

\section{c. Pembuatan spesimen pengujian}


196 Syaharuddin R, Abram T, M. Hasmar Hasbullah, M. Al-Fandi. Analisis Struktur Mikro Globular Dan Kekerasan Paduan Aluminium ADC12 Pada Pengecoran Semi Solid Dengan Metode Stir Casting

Ada dua macam spesimen yang akan dibuat, yaitu spesimen untuk uji kekerasan dan spesimen untuk mengetahui struktur mikro dari aluminium.

1. Sebelum spesimen diuji dilakukan penggoresan pada spesimen supaya mudah pada saat dilakukan pengujian.

2. Spesimen uji kekerasan diambil dari benda kerja hasil pengecoran.

3.Pembuatan spesimen untuk mengetahui struktur mikro dimulai dari pemotongan benda kerja hasil pengecoran dengan ukuran 10x10x10 mm. Kemudian diletakan di dalam tutup botol air mineral, lalu dituangkan cairan resin yang telah dicampur dengan hardener. Setelah itu, ditunggu hingga tersebut mengeras. Selanjutnya dilakukan pengamplasan secara bertahap dengan kertas amplas 200, 400, 600, 800, 1000, 1500, 2000, 4000, dan 5000 menggunakan mesin amplas.

\section{d. Proses Pengujian}

Proses pengujian merupakan tahapan dalam pengumpulan data penelitian. Data hasil pengujian merupakan nilai sifat mekanik hasil pengecoran yaitu nilai kekerasan dan serta pengujian struktur mikro. Proses pengujian benda kerja diuraikan sebagai berikut:

\section{Pengujian kekerasan}

Pengujian kekerasan dilakukan untuk mendapatkan nilai kekerasan pada beberapa daerah hasil pengecoran. Uji kekerasan ini dilakukan menggunakan mesin Affri Hardnes Tester Series 206 MX

\section{Struktur Mikro}

Sebelum melakukan pengujian struktur mikro diperlukan perlakuan tertentu pada bahan, yaitu pemolesan untuk mendapatkan bentuk butir pada bahan. Dalam pengujian ini kualitas bahan ditentukan dengan mengamati struktur dibawah mikroskop.

\section{Teknik Analisis Data}

Teknik analisis data ialah tahapan dalam mengolah dan menganalisis data pengujian yang diperoleh. Data pengujian yang diperoleh akan diolah dan dianalisis menggunakan metode software Microsoft Excel.

\section{HASIL DAN PEMBAHASAN}

\section{A. Analisis Komposisi Paduan Aluminium ADC12}

Paduan aluminium ADC12 digunakan dalam penelitian dan memiliki komposisi seperti yang tercantum pada tabel berikut:

Tabel 1 Komposisi Paduan Aluminium ADC12.

\begin{tabular}{|l|c|c|c|c|c|c|c|c|c|c|c|c|}
\hline \multirow{2}{*}{ Paduan } & \multicolumn{10}{|c|}{ Berat \% } \\
\cline { 2 - 13 } & $\mathrm{Si}$ & $\mathrm{Cu}$ & $\mathrm{Fe}$ & $\mathrm{Mn}$ & $\mathrm{Mg}$ & $\mathrm{Zn}$ & $\mathrm{Ti}$ & $\mathrm{Cr}$ & $\mathrm{Ni}$ & $\mathrm{Pb}$ & $\mathrm{Sn}$ & $\mathrm{Al}$ \\
\hline ADC12 & 9.55 & 2.01 & 0.91 & 0.16 & 0.22 & 1.31 & 0.03 & 0.02 & 0.14 & 0.11 & 0.02 & 85.49 \\
\hline
\end{tabular}

Berdasarkan hasil analisis pengujian komposisi paduan aluminium ADC12 dapat dilihat bahwa kandungan Si pada bahan ini adalah 9.55\%. Hal ini menunjukkan bahwa paduan aluminium ADC12 yang digunakan termasuk jenis paduan $\mathrm{Al}$-Si hypoeutectoid (medium silicon) dengan temperature beku $615^{\circ} \mathrm{C}-550^{\circ} \mathrm{C}[3-5]$.

\section{B. Analisis Struktur Mikro}

Menampilkan foto stuktur mikro pada aluminium ADC12 pada variasi sudut pengaduk, putaran pengaduk dan suhu tuang. Gambar dibawah memperlihatkan perbandingan struktur mikro pada paduan 
aluminium ADC 12 yang diaduk dengan pengaduk mekanik (variasi sudut pengaduk, pembesaran 200X, suhu tuang $565^{\circ} \mathrm{C}$, putaran $400 \mathrm{rpm}$ dan waktu pengadukan selama 20 detik).

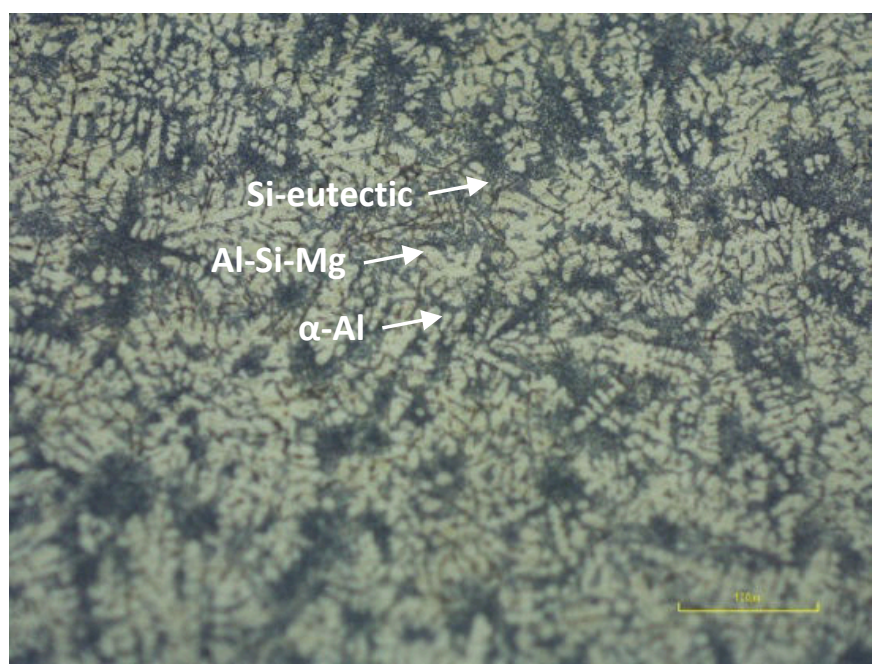

(a)

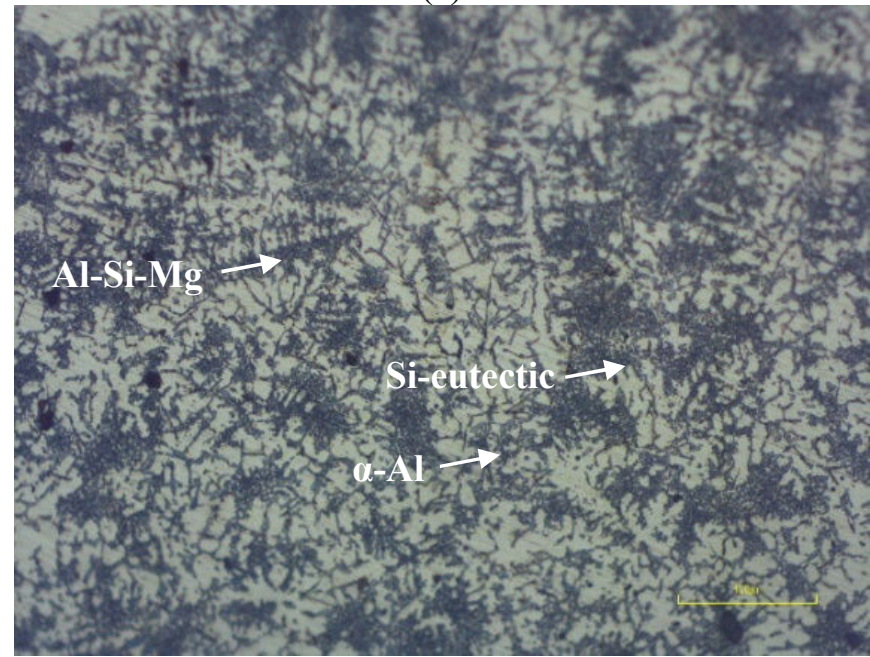

(b)

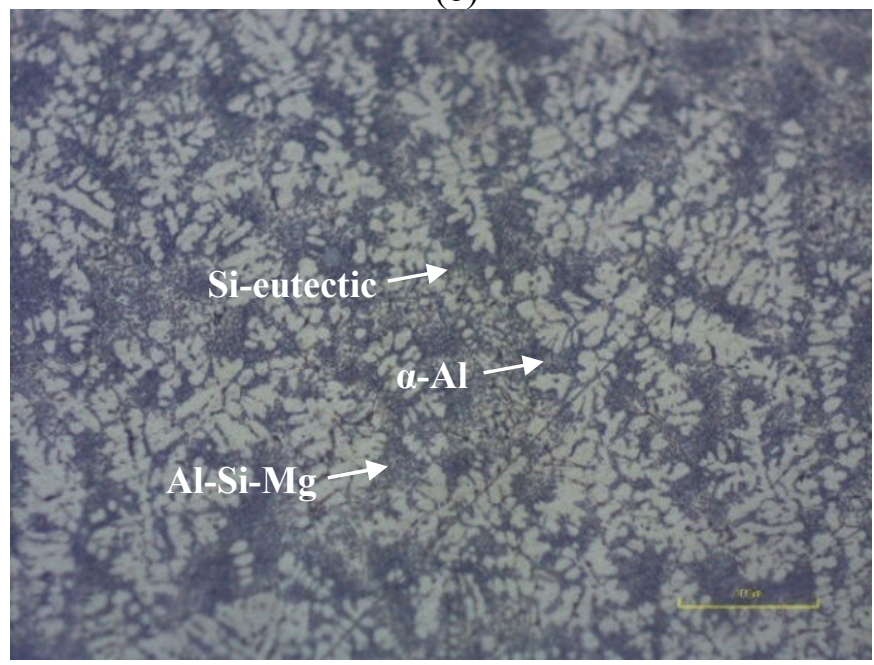

(c) 
198 Syaharuddin R, Abram T, M. Hasmar Hasbullah, M. Al-Fandi. Analisis Struktur Mikro Globular Dan Kekerasan Paduan Aluminium ADC12 Pada Pengecoran Semi Solid Dengan Metode Stir Casting

Gambar 1. Struktur mikro ADC12 hasil pengecoran dengan metode stir casting sudut pengaduk; a $)=0^{\circ}$,

(b) $=15^{\circ}$, dan $(\mathrm{c})=30^{\circ}$.

Berdasarkan hasil pengamatan pada Gambar 1a., dapat dilihat bahwa unsur silikon (hitam) pada paduan aluminium lebih merata di dalam matriks aluminium (putih) yang diaduk dengan sudut pengaduk $0^{\circ}$ bila dibandingkan dengan struktur mikro pada Gambar 1b. (sudut pengaduk $15^{\circ}$ ) dan Gambar 1c. (sudut pengaduk $30^{\circ}$ ). Bila unsur Si relatif lebih merata, maka sifat mekanik paduan aluminium ADC12 lebih baik.

Jika ditinjau dari ukuran butir, maka Gambar 1a. memiliki ukuran butir relatif lebih kecil dan merata dari pada ukuran butir pada Gambar 1b. dan Gambar 1c. Ukuran butir yang lebih kecil memiliki sifat mekanik yang lebih baik.

\section{Ukuran Butir (Grain Size)}

Grafik hubungan antara ukuran butir dan putaran pengaduk paduan aluminium ADC12 dapat dilihat pada Gambar 2.

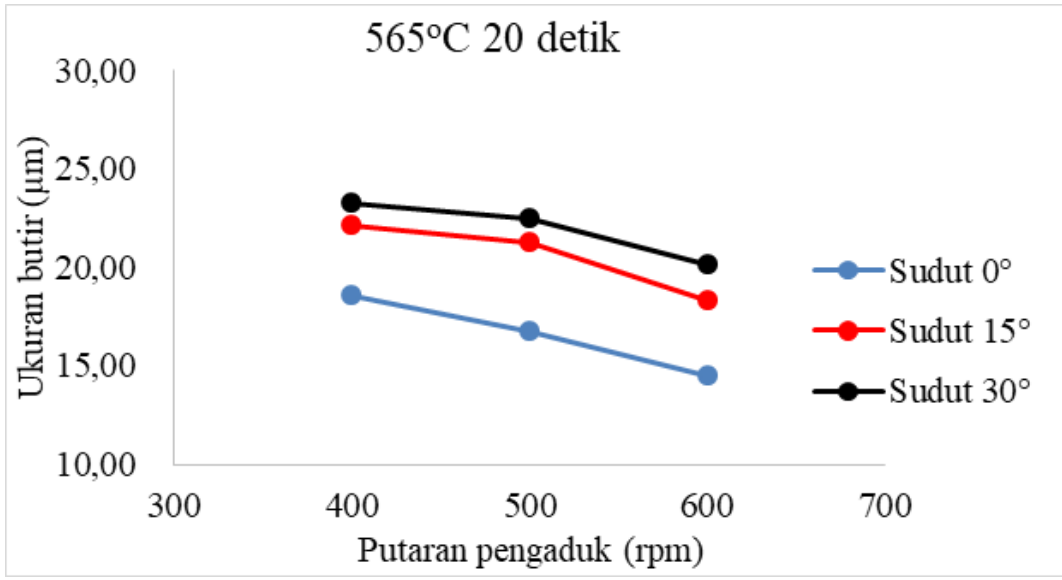

(a)

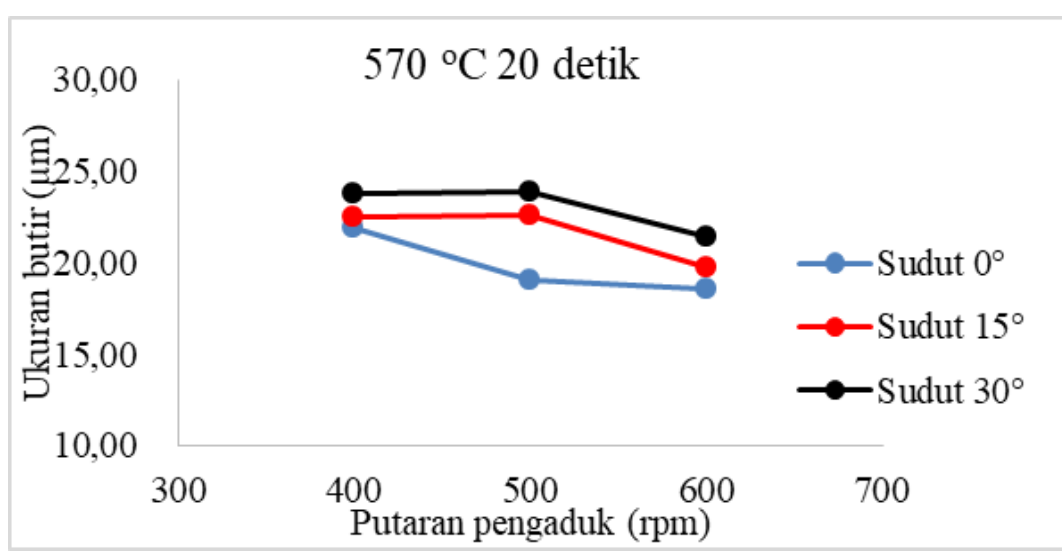

(b) 


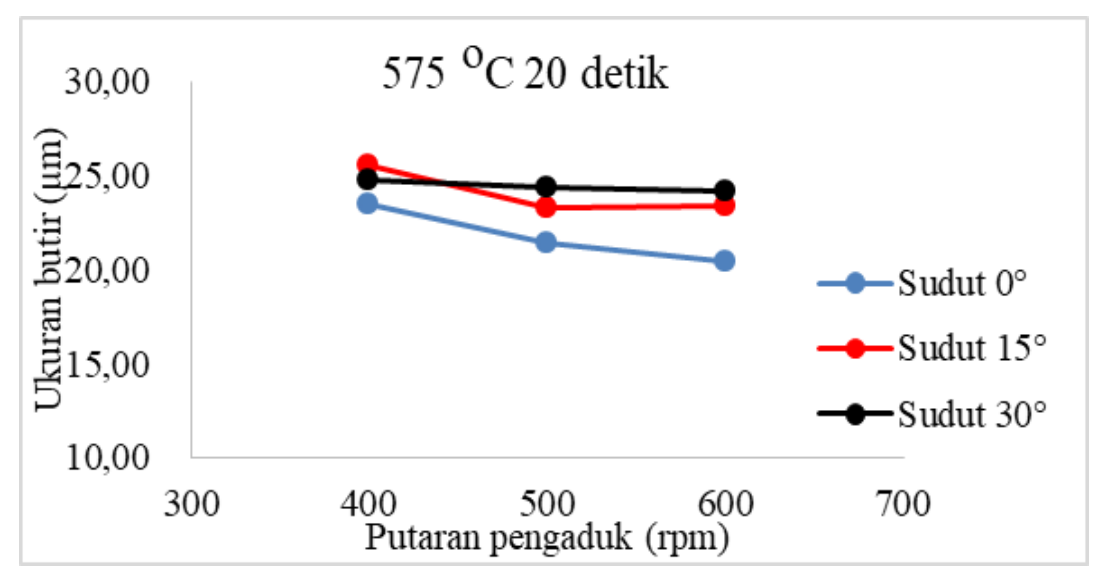

(c)

Gambar 2. Grafik ukuran butir ADC12 terhadap putaran pengaduk ; (a) $=565^{\circ} \mathrm{C}, 20 \mathrm{detik},(\mathrm{b})=570^{\circ} \mathrm{C}$, (c) $=575^{\circ} \mathrm{C}$

Berdasarkan hasil pengamatan pada Gambar 2 bahwa semakin besar putaran pengaduk maka ukuran butir semakin kecil. Hal ini terjadi karena dengan meningkatnya kecepatan putar pengaduk maka gaya geser yang diberikan kepada slurry aluminium semakin besar. Gaya geser yang diberikan pada slurry aluminium akan menghambat pertumbuhan butir sehingga struktur dendritic dapat diubah menjadi non-dendritic. Hasil ini sesuai dengan hasil penelitian $[4,6,7]$ yang menyatakan bahwa pengadukan ditunjukkan untuk mempengaruhi ukuran partikel rata-rata terutama selama tahap awal pembekuan. Meskipun faktor bentuk rata-rata partikel primer relatif tidak sensitif terhadap variasi besar dalam kecepatan pengadukan, kecepatan pengadukan yang lebih tinggi membuat bentuk dan ukuran partikel primer lebih seragam. Kecepatan pengadukan yang lebih tinggi juga menghasilkan aglomerat partikel primer yang lebih kecil dan lebih bulat.

Bila ditinjau dari variasi sudut pengaduk, maka sudut pengaduk $0^{\circ}$ menghasilkan ukuran butir lebih kecil dari sudut pengaduk lainnya $\left(15^{\circ}\right.$ dan $\left.30^{\circ}\right)$. Fenomena ini terjadi pada suhu tuang $565^{\circ} \mathrm{C}$, $570^{\circ} \mathrm{C}$, dan $575^{\circ} \mathrm{C}$.

\section{Faktor Bentuk (Shape factor)}

Grafik hubungan antara faktor bentuk dan putaran pengaduk paduan aluminium ADC12 dapat dilihat pada Gambar 3 dibawah ini.

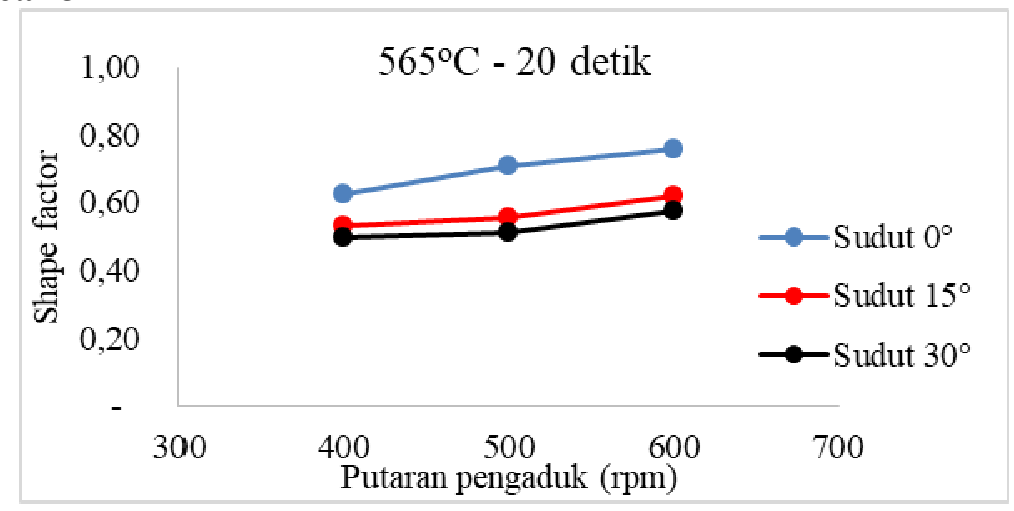

(a) 
200 Syaharuddin R, Abram T, M. Hasmar Hasbullah, M. Al-Fandi. Analisis Struktur Mikro Globular Dan Kekerasan Paduan Aluminium ADC12 Pada Pengecoran Semi Solid Dengan Metode Stir Casting

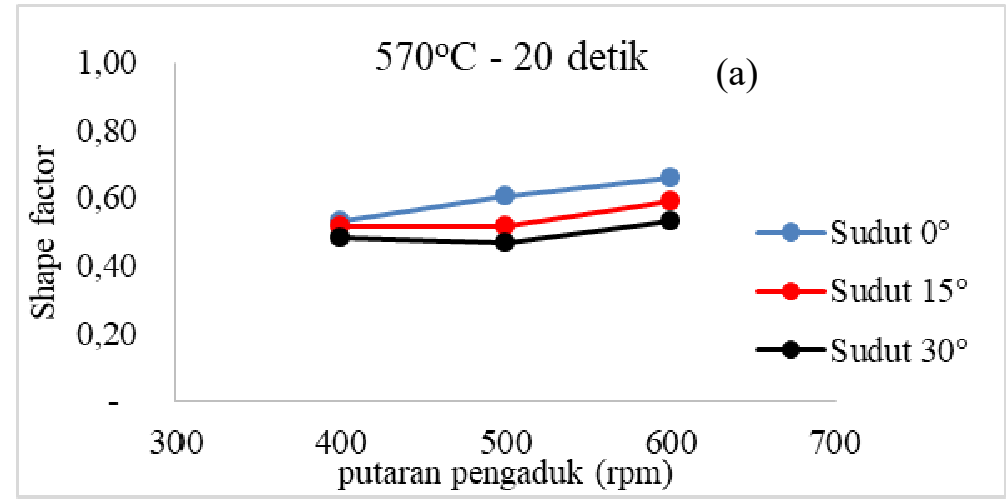

(b)

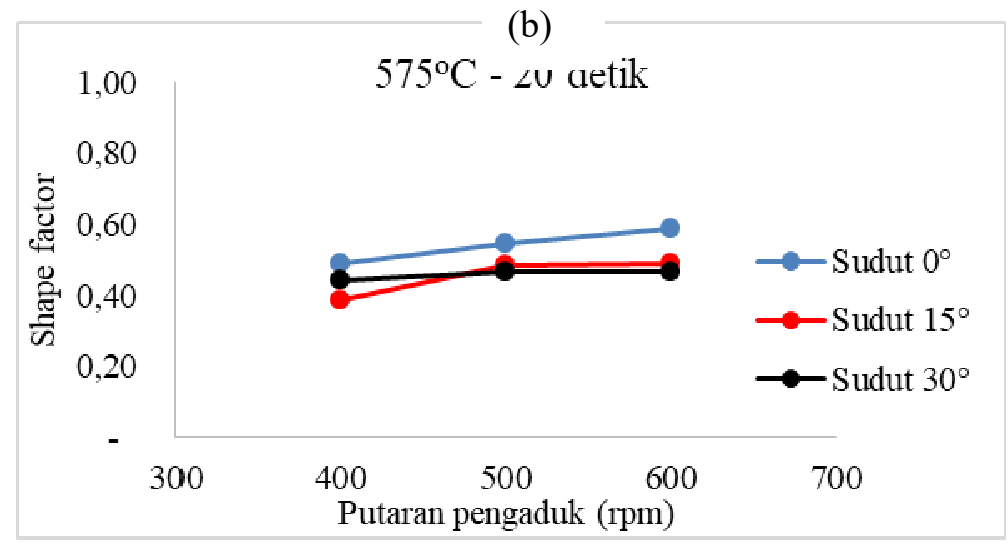

(c)

Gambar 3. Grafik Faktor Bentuk ADC12 Terhadap Putaran pengaduk ; (a) $=565^{\circ} \mathrm{C}, 20 \mathrm{detik},(\mathrm{b})=570^{\circ} \mathrm{C}$, (c) $=575^{\circ} \mathrm{C}, 20$ detik

Berdasarkan hasil pengamatan pada Gambar 3. diketahui bahwa semakin besar putaran pengaduk maka faktor bentuk semakin besar. Hal ini terjadi karena dengan meningkatnya kecepatan putar pengaduk maka gaya geser yang diberikan kepada slurry aluminium semakin besar. Gaya geser yang diberikan pada slurry aluminium akan menghambat pertumbuhan butir menjadi dendritis dan struktur mikro cenderung non-dendritis. Faktor bentuk terbesar terjadi pada parameter sudut pengaduk $0^{0}$, putaran $600 \mathrm{rpm}$, dan dan suhu tuang $565^{\circ} \mathrm{C}$ dengan nilai 0.76 . Hasil ini sesuai dengan hasil penelitian yang dilakukan oleh $[\mathbf{4 , 6 , 7 ]}$ yang menyatakan bahwa pengadukan ditujukan untuk mempengaruhi ukuran partikel rata-rata terutama selama tahap awal pembekuan. Meskipun faktor bentuk rata-rata partikel primer relatif tidak sensitif terhadap variasi besar dalam kecepatan pengadukan, kecepatan pengadukan yang lebih tinggi membuat bentuk dan ukuran partikel primer lebih seragam. Kecepatan pengadukan yang lebih tinggi juga menghasilkan aglomerat partikel primer yang lebih kecil dan lebih bulat.

Bila ditinjau dari variasi sudut pengaduk, maka sudut pengaduk $30^{\circ}$ menghasilkan factor bentuk lebih kecil dari sudut pengaduk lainnya $\left(0^{\circ}\right.$ dan $\left.15^{\circ}\right)$. Fenomena ini terjadi pada temperature tuang $565^{\circ} \mathrm{C}, 570^{\circ} \mathrm{C}$, dan $575^{\circ} \mathrm{C}$.

\section{E. Kekerasan}

Grafik hubungan antara kekerasan dan putaran pengaduk paduan aluminium ADC12 dapat dilihat pada Gambar 4. 


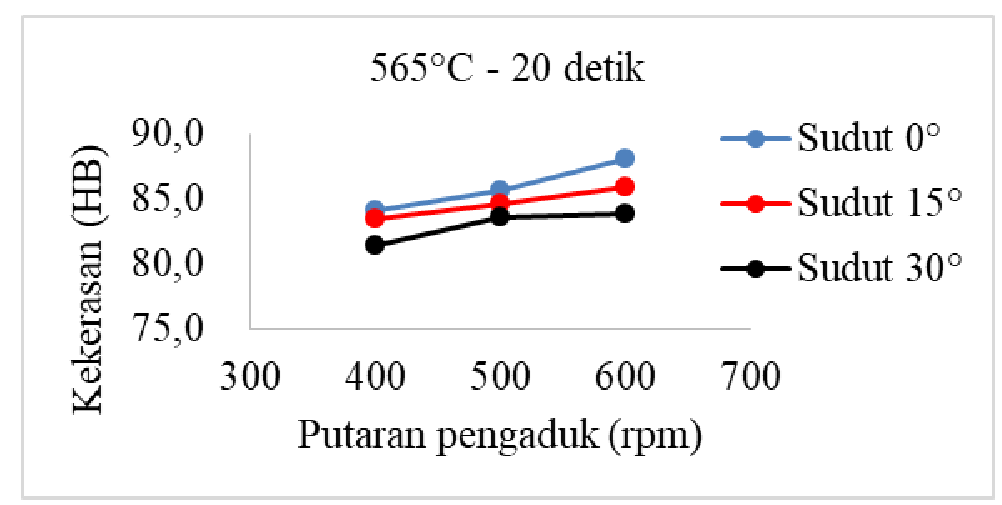

(a)

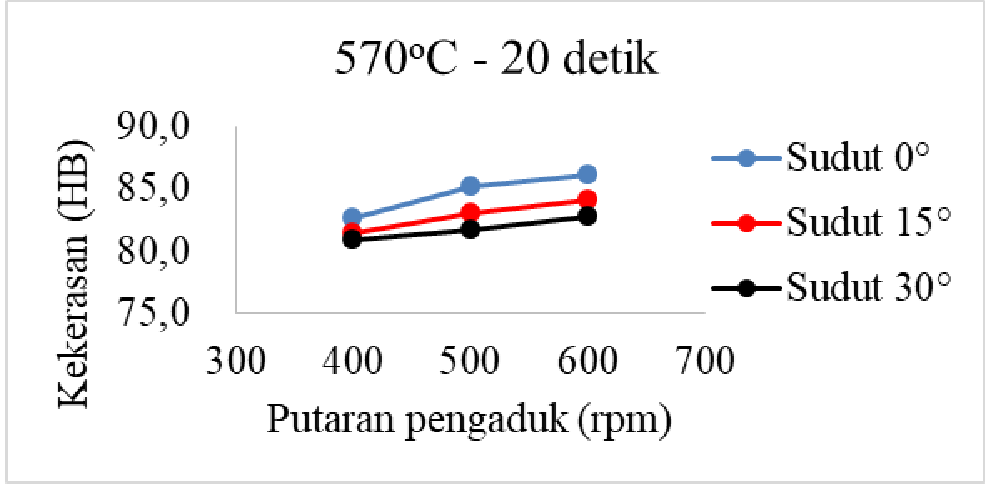

(b)

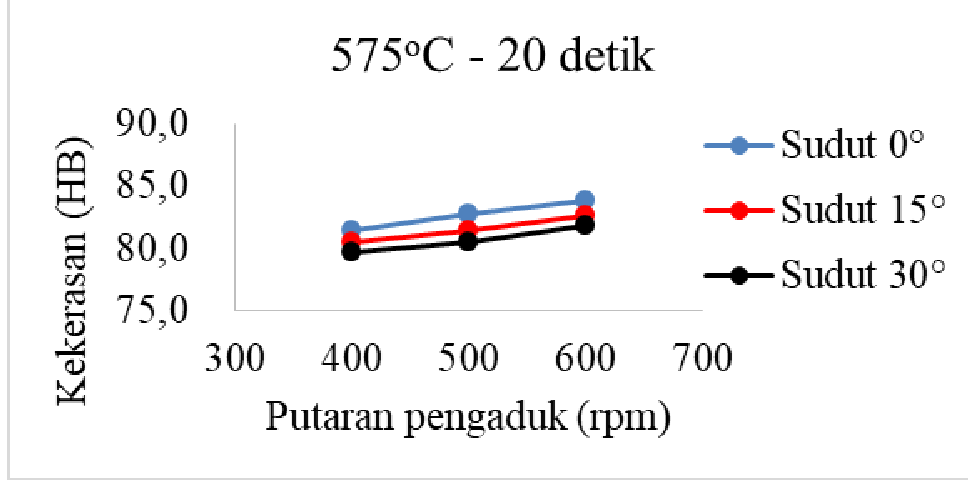

(c)

Gambar 4. Grafik kekerasan $\mathrm{ADC} 12$ terhadap putaran pengaduk. ; (a) $=565^{\circ} \mathrm{C}, 20 \mathrm{detik},(\mathrm{b})=570^{\circ} \mathrm{C}$, (c) $=575^{\circ} \mathrm{C}, 20$ detik

Berdasarkan hasil pengamatan pada Gambar diatas diketahui bahwa semakin besar putaran pengaduk maka nilai kekerasan semakin meningkat. Hasil ini diperkuat oleh ukuran butir semakin kecil seiring dengan naiknya kecepatan putar. Ukuran butir yang berukuran lebih kecil akan menghasilkan ikatan atom yang lebih kuat dan hal ini akan berdampak pada meningkatnya kekerasan.

Bila ditinjau dari variasi sudut pengaduk, maka sudut pengaduk $0^{\circ}$ menghasilkan kekerasan lebih besar dari sudut pengaduk lainnya. Dan nilai terkecil ada pada sudut pengaduk $30^{\circ}$.

\section{KESIMPULAN}

Berdasarkan hasil penelitian yang telah dilakukan yaitu pengecoran menggunakan material Aluminium Paduan (Al-Si) ADC12 dapat disimpulkan bahwa: 
a) Unsur paduan silikon ( $\mathrm{Si}$ ), dalam matrix aluminium lebih merata dengan menggunakan pengaduk dengan sudut pengaduk $0^{\circ}$.

b) Ukuran butir terkecil terjadi pada parameter pengecoran: sudut pengaduk $0^{\circ}$, putaran $600 \mathrm{rpm}$, dan suhu tuang $565^{\circ} \mathrm{C}$ dengan nilai $27,715 \mathrm{~mm}$. Kemudian diikuti dengan pengaduk dengan sudut pengaduk $15^{\circ}$ dan $30^{\circ}$ dengan nilai 27,523 dan $51,767 \mathrm{~mm}$.

c) Faktor bentuk terbesar terjadi pada parameter pengecoran: sudut pengaduk $0^{\circ}$, putaran 600 $\mathrm{rpm}$, dan dan suhu tuang $565^{\circ} \mathrm{C}$ dengan nilai 0.76 . Kemudian diikuti dengan pengaduk dengan sudut pengaduk $15^{\circ}$ dan $30^{\circ}$ dengan nilai 0.62 dan 0.58 .

d) Kekerasan tertinggi terjadi pada parameter pengecoran: sudut pengaduk $0^{\circ}$, putaran $600 \mathrm{rpm}$, dan dan suhu tuang $565^{\circ} \mathrm{C}$ dengan nilai $88,0 \mathrm{HB}$. Kemudian diikuti dengan pengaduk dengan sudut pengaduk $15^{\circ}$ dan $30^{\circ}$ dengan nilai $85,8 \mathrm{HB}$ dan $83,9 \mathrm{HB}$.

\section{DAFTAR PUSTAKA}

[1] Sutantra, I.N, “ Teknologi Otomotif”, Surabaya: Guna Widya, 2001.

[2] Rasyid S, Arif E, Arsyad H, and Syahid M. "Effects of stirring parameters on the rheocast microstructure and mechanical properties of aluminum alloy ADC12". in MATEC Web of Conferences 2018, 12004-197

[3] ASM, Handbook, Casting, Volume 15. ASM International, Materials Park, OH. 1998

[4] Rasyid S, Arif E, Arsyad H, Syahid M. "Effect of mechanical stirrer and pouring temperature on semi solid rheocasting of ADC12 al alloy", mechanical properties and microstructure J. of Eng. and App. ARPN Journal of Engineering and Applied Sciences.(13-6). 2018. 2032-7

[5] Rasyid S, Arif E, Arsyad H, Syahid M. "Effects of stirring parameters on the rheocast microstructure and mechanical properties of aluminum alloy ADC12" in MATEC Web of Conferences EDP Sciences, 2018. Vol. 197, p. 12004.

[6] Rasyid S, Renreng I, Arif E, Arsyad H, Syahid M. "Optimization of stirring parameters on the rheocast microstructure and mechanical properties of aluminum alloy ADC12" in IOP Conference Series: Materials Science and Engineering IOP Publishing, 2019. Vol. 619, No. 1, p. 012028,

[7] Rasyid S, Muas. "Analisis sifat mekanik dan struktur mikro paduan aluminium ADC12 dengan teknik pengecoran semi solid (rheocasting)", in Seminar Nasional Hasil Penelitian \& Pengabdian Kepada Masyarakat (SNP2M), Aug 28, 2018. 